\title{
NPY and Gene Therapy for Epilepsy: How, When,... and $Y$
}

\author{
Stefano Cattaneo ${ }^{1,2}$, Gianluca Verlengia ${ }^{2,3}$, Pietro Marino ${ }^{3,4}$, Michele Simonato ${ }^{1,2,3}$ and \\ Barbara Bettegazzi ${ }^{1,2 *}$
}

${ }^{1}$ Vita-Salute San Raffaele University, Milan, Italy, ${ }^{2}$ San Raffaele Scientific Institute, Milan, Italy, ${ }^{3}$ Department of Neuroscience and Rehabilitation, Section of Pharmacology, University of Ferrara, Ferrara, Italy, ${ }^{4}$ Department of Medical Sciences, Section of Pediatrics, University of Ferrara, Ferrara, Italy

OPEN ACCESS

Edited by:

Marco Ledri,

Lund University, Sweden

Reviewed by:

Gunther Sperk

Innsbruck Medical University, Austria

Deniz Yilmazer-Hanke,

University of UIm, Germany

*Correspondence:

Barbara Bettegazzi

bettegazzi.barbara@hsr.it

Received: 18 September 2020 Accepted: 21 December 2020

Published: 22 January 2021

Citation:

Cattaneo S, Verlengia G, Marino $P$, Simonato $M$ and Bettegazzi B (2021) NPY and Gene Therapy for Epilepsy: How, When,... and Y.

Front. Mol. Neurosci. 13:608001 doi: 10.3389/fnmol.2020.608001
Neuropeptide Y (NPY) is a neuropeptide abundantly expressed in the mammalian central and peripheral nervous system. NPY is a pleiotropic molecule, which influences cell proliferation, cardiovascular and metabolic function, pain and neuronal excitability. In the central nervous system, NPY acts as a neuromodulator, affecting pathways that range from cellular (excitability, neurogenesis) to circuit level (food intake, stress response, pain perception). NPY has a broad repertoire of receptor subtypes, each activating specific signaling pathways in different tissues and cellular sub-regions. In the context of epilepsy, NPY is thought to act as an endogenous anticonvulsant that performs its action through Y2 and Y5 receptors. In fact, its overexpression in the brain with the aid of viral vectors can suppress seizures in animal models of epilepsy. Therefore, NPY-based gene therapy may represent a novel approach for the treatment of epilepsy patients, particularly for pharmaco-resistant and genetic forms of the disease. Nonetheless, considering all the aforementioned aspects of NPY signaling, the study of possible NPY applications as a therapeutic molecule is not devoid of critical aspects. The present review will summarize data related to NPY biology, focusing on its anti-epileptic effects, with a critical appraisal of key elements that could be exploited to improve the already existing NPY-based gene therapy approaches for epilepsy.

Keywords: viral vectors, epilepsy, gene therapy, Y2 receptor, NPY

\section{NPY DISCOVERY, EVOLUTION, AND FUNCTION}

Described in 1982, neuropeptide Y (NPY) is a 36-aminoacid peptide that shares high homology with its family members pancreatic peptide (PP) and peptide YY (PYY). The NPY ancestral gene appeared in vertebrates, evolving from an ortholog NPY-like system that regulates energy homeostasis in invertebrates acting on growth and reproduction (De Jong-Brink et al., 2001; Kooijman and Troost, 2007; Gershkovich et al., 2019). The family of Y peptides probably originated through a chromosome quadruplication event that took place during jawed vertebrate emergence (Larhammar and Salaneck, 2004).

NPY has a widespread expression throughout the central (CNS) and peripheral nervous system (PNS) and it is typically co-released with other neurotransmitters. An unusually broad repertoire of receptor subtypes mediate its actions, each activating specific signaling pathways in different tissues and cellular sub-regions (Leblanc et al., 1987; Keast, 1991; Dumont et al., 1992; Elfvin et al., 1997; Cerdá-Reverter and Larhammar, 2000; Wai et al., 2004). 
During evolution, the NPY-like system has increased the complexity of its actions, with effects that in humans range from cell proliferation to the control of energy metabolism, pain and neuronal activity (Kuo et al., 2007; Tilan and Kitlinska, 2016). NPY is involved in cardiovascular and metabolic diseases, as well as in respiratory and neurologic disorders (Pedrazzini et al., 2003; Vezzani and Sperk, 2004; Atanasova and Reznikov, 2018), acting as a paracrine hormone in the periphery and behaving like a neuromodulator in the CNS.

In the CNS, NPY exerts its modulatory action both at cellular (excitability, neurogenesis) and at circuit level (food intake, stress response, and pain perception). It is expressed in different areas of the brain, from the neocortex to the posterior root of spinal nerves, usually in GABAergic interneurons, but also in long projecting catecholaminergic neurons; e.g., in the brainstem and in certain hypothalamic nuclei (Chronwall et al., 1985; de Quidt and Emson, 1986; Silva et al., 2005a; Benarroch, 2009). In the mesial temporal lobe, NPY is widely expressed in different subnuclei of the amygdala, where it is thought to exert a potent anxiolytic effect (Tasan et al., 2010; Wood et al., 2016), and in the hippocampus, where it displays an inhibitory action on excitatory synaptic transmission, mostly by reducing glutamate release (Colmers et al., 1985; Klapstein and Colmers, 1992; Greber et al., 1994; Mcquiston and Colmers, 1996). It is worth noting that, coherently with its homeostatic role, NPY projecting neurons are also close to circumventricular organs and sensory/secretory blood-brain interfaces (Wagner et al., 2015).

\section{GENE STRUCTURE}

The human NPY gene $(\sim 8 \mathrm{~kb})$ is located on chromosome 7p15 (genomic coordinates (GRCh38): 7:24,284,189-24,291,861). Regulatory elements have been found within 530 bases from the transcription start site and further regulatory sequences enhancing transcription and mRNA stability may be present up/downstream that region or even inside introns (Waldbieser et al., 1992; Waschek, 1995; Zhou et al., 2008). Single nucleotide polymorphisms (SNPs) in the coding region may increase NPY synthesis (Mitchell et al., 2008). The full length mRNA is $551 \mathrm{bp}$ long (Minth et al., 1984). After translation in the endoplasmic reticulum, upon signal peptide truncation, NPY is directed to the secretory pathway.

\section{PEPTIDE TRAFFICKING, PROCESSING AND RELEASE}

While trafficking inside dense core vesicles (DCVs), the full coding sequence of NPY, prepro-NPY, is sequentially split into three fragments (Figure 1A): (1) an N-terminus 28amino acid (aa) signaling peptide, (2) the mature 36 aa, $4.2 \mathrm{kDa}$, peptide $\left(\mathrm{NPY}_{1-36}\right)$, and (3) a 30-aa C-terminal flanking peptide of neuropeptide-Y (CPON). A glycine-lysinearginine (G-K-R) site in proximity of the C-terminus of the mature 36 aa peptide is crucial for $\mathrm{CPON}$ cleavage by prohormone convertases and for the amidation of the mature
NPY, performed by carboxypeptidase E and peptidyl-glycin$\alpha$-amidating monooxygenase. The CPON structure is highly conserved during evolution (Cerdá-Reverter and Larhammar, 2000). It has been suggested that it may play a role in epilepsy control, but current data do not confirm this hypothesis (Soud et al., 2019).

NPY and CPON containing DCVs are released upon calcium influx. The need of a long, high frequency firing rate for NPY release (Lundberg et al., 1986; van den Pol, 2012) has been questioned by evidence that NPY is released by hippocampal neurons even during physiological synaptic activity (Li et al., 2017).

\section{METABOLISM}

Once released in the extracellular space, mature NPY can bind to its receptors and activate signal transduction (Walther et al., 2011) or be metabolized, either close or far away from its release site, in the cerebrospinal fluid or in the blood. Proteolytic processing can alter the NPY signaling at either the N-terminal or C-terminal portion of the peptide and usually results in a modification of receptor binding affinity or inactivation followed by complete degradation, depending on a number of peptidases with compartment-dependent concentration and activity (Allen et al., 1987; Wagner et al., 2015).

The most common pathway of NPY metabolism is N-terminal cleavage by dipeptidyl peptidase IV (DP4) which is responsible for the formation of $\mathrm{NPY}_{3-36}$, followed by C-terminal processing by enzymes like kallikrein, cathepsins or angiotensin-converting enzyme (ACE) that in turn yield inactive NPY fragments. Aminopeptidase (AmP) instead produces $\mathrm{NPY}_{2-36}$, catalyzing a less efficient cleavage within the $\mathrm{N}$-terminal region compared to $\mathrm{DP} 4$, which results in a lower relative concentration of this metabolite (Abid et al., 2009). Both $\mathrm{NPY}_{3-36}$ and $\mathrm{NPY}_{2-36}$ display a decreased affinity for Y1 receptors, therefore preferentially binding to other (Y2 and Y5) receptor subtypes (Grandt et al., 1996; Hubers et al., 2018; Yang et al., 2018).

After inactivation, other plasmatic peptidases catalyze the metabolism of smaller fragments, with the kidney playing a major role in residual NPY metabolism (Satoh et al., 1999). The estimated plasma half-life in human and animal studies is between 5 and 20 min (Pernow et al., 1986; Potter, 1987).

\section{NPY RECEPTORS}

The NPY system is not only multi-ligand, as described above, but also multi-receptor, and this makes it a complex target for therapeutic applications.

In fact, five different NPY receptors are expressed in mammals: Y1, Y2, Y4, Y5, and y6. While Y1, Y2, Y4, and Y5 are functional in all mammals, y6 is a pseudogene in humans and other primates and is missing also in the rat genome (Larhammar and Salaneck, 2004). NPY displays an especially high affinity for the Y1, Y2, and Y5 receptor subtypes: even if structurally different, these three receptors can respond to the same ligands. Y1 and Y4 form a receptor superfamily, while Y2 and Y5 have 


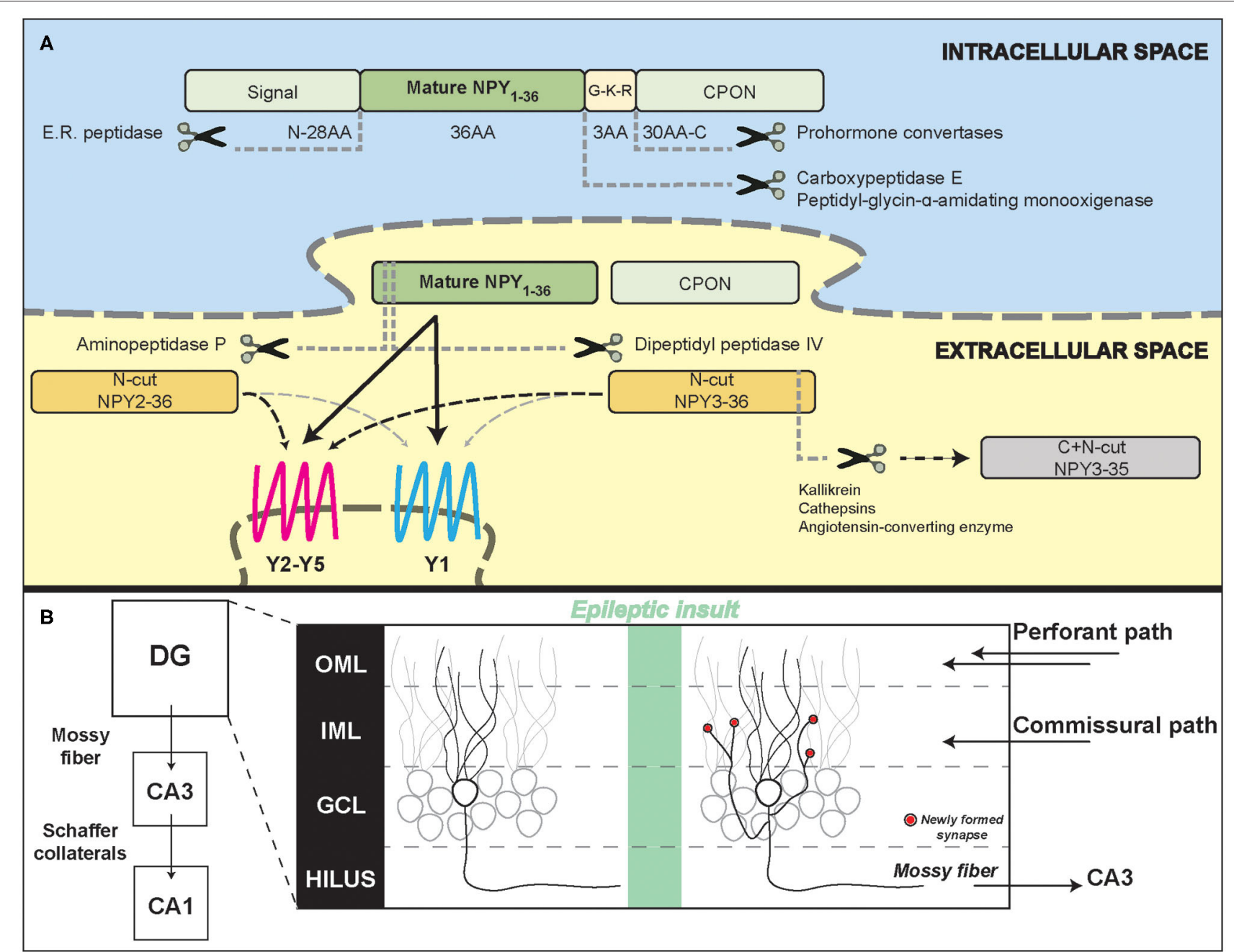

FIGURE 1 | Neuropeptide Y processing and its potential role in the epileptic hippocampal network. (A) Schematic representation of NPY intracellular processing and extracellular metabolism. (B) Illustration of hippocampal formation rearrangements after an epileptic insult. Red dots represent synapses newly formed by the mossy fiber sprouting in the inner molecular layer that contain NPY and pre-synaptic Y2 receptors. DG, dentate gyrus; CA3/CA1, Cornu Ammonis; OML, outer molecular layer; IML, inner molecular layer; GCL, granule cell layer.

distinct, individual features (Larhammar and Salaneck, 2004). NPY receptors (YRs) have different affinities for the Y family hormone ligands, with Y4Rs binding preferably PP and Y2Rs binding NPY and N-terminally truncated peptides with similar affinity (Lindner et al., 2008). The genes encoding for NPY receptors are located on human chromosome 4 and probably arose by a duplication event from an ancestral NPY/PYYbinding receptor. All NPY receptors are widely expressed in the mammal brain, Y2 being the most abundant (Dumont et al., 1998). High levels of NPY binding can be revealed in the cortex, hippocampus, amygdala, striatum and cerebellum (Dumont et al., 1993).

Specific binding to $\mathrm{Y} 1$ receptors can be visualized in different layers of the cortex, in the CA1 and CA3 stratum radiatum, oriens, in the dentate gyrus of the hippocampus in the amygdala, striatum, cerebellum and, at lower levels, in some thalamic, hypothalamic and brainstem nuclei (Dumont et al., 1990, 1993; Aicher et al., 1991; Cabrele and Beck-Sickinger, 2000; Kopp et al., 2002). Outside the CNS, Y1Rs are also found in the adipose tissue and in vascular smooth muscle cells (Castan et al., 1993; Lindner et al., 2008). Y1Rs are mainly localized postsynaptically in neurons of the hippocampus (especially in CA3, CA1 and dentate gyrus), striatum and cortex (Wahlestedt et al., 1986; Caberlotto, 1997; Kopp et al., 2002), with a prominent somatic and dendritic localization (Kopp et al., 2002). However, some studies also suggest a pre-synaptic localization (Colmers et al., 1987, 1988; Flood and Morley, 1989; Pickel et al., 1998; Brumovsky et al., 2002; Glass et al., 2002; Kopp et al., 2002; Stanić et al., 2006; Li et al., 2017). Albeit NPY and Y1R scarcely co-localize (Stanić et al., 2011), the presence of Y1R on the cell soma of NPY-containing hilar interneurons and cultured hippocampal neurons is suggestive of a possible role 
of these receptors in an autoinhibitory feedback (St-Pierre et al., 2000; Paredes et al., 2003).

Together with Y5Rs, Y1Rs play an important role in regulating feeding behavior and energy homeostasis (Baldock et al., 2007; Nguyen et al., 2012). Y1R-mediated antidepressant and anxiolytic effects have been described in rodents (Wahlestedt et al., 1993; Verma et al., 2012), while the role in epilepsy remains controversial (see below). The anxiolytic effect of NPY in the basolateral amygdala has been attributed to the activation of Y1Rs (Sajdyk et al., 2004; Giesbrecht et al., 2010).

Y2Rs are expressed in many brain regions, including the hippocampus, thalamus, hypothalamus and cortex; in the peripheral nervous system, Y2Rs are found in parasympathetic, sympathetic and sensory neurons; finally, they are also present in the intestine and in certain blood vessels (Wahlestedt et al., 1986; Stjernquist and Owman, 1990; Gehlert et al., 1992; Dumont et al., 1993; Rettenbacher and Reubi, 2001). In the hippocampus, Y2 receptors are particularly enriched in the CA1 and CA3 areas, respectively in the stratum radiatum and in the pyramidal cell layer (Colmers et al., 1987, 1988, 1991; Monnet et al., 1992). Expression of Y1 and Y2 receptors is often complementary. For example, high levels of Y2Rs are detectable in the stratum oriens and radiatum of CA1-CA3, where Y1 receptor levels are relatively low, while the opposite is true in the dentate gyrus molecular layer (Stanić et al., 2011). Y2Rs are highly expressed in the terminal regions of mossy fibers and Schaffer collaterals (Jacques et al., 1997), where they act presynaptically by inhibiting calcium-mediated neurotransmitter release (Klapstein and Colmers, 1993). While NPY and a Y2R selective agonist inhibit evoked EPSPs on CA1 pyramidal cells, a Y2R selective antagonist is able to block the inhibitory action of NPY on glutamate release (El Bahh et al., 2002).

Y2Rs are expressed by both GABAergic and glutamatergic terminals (Stanić et al., 2006, 2011) and may therefore inhibit the release of both neurotransmitters, in particular under chronic epileptic conditions (Martire et al., 1993; Greber et al., 1994; Klapstein and Colmers, 1997; Vezzani and Sperk, 2004; Silva et al., 2005b). This makes Y2Rs an interesting target in epilepsy (Vezzani and Sperk, 2004). Y2Rs can also be localized along the course of axons in fiber tracts (in Schaffer collaterals, the fimbria and the stria terminalis (Dum et al., 2017)). These receptors are functionally coupled with G-protein signaling and show high affinity for their ligand (Dum et al., 2017), leaving open the possibility of a modulation through NPY volume transmission.

Y5Rs are mainly found in the hypothalamus and in the hippocampus (in the pyramidal cell layer of the CA2 region, with lower concentrations in the hilar region of the dentate gyrus and in the CA3 subregion), where they participate in the modulation of hippocampal excitability (Gerald et al., 1996; Dumont et al., 1998; Guo et al., 2002). Together with Y1Rs, Y5Rs contribute to the regulation of food intake and energy homeostasis, but they also display anticonvulsant effects (Woldbye et al., 1997; Criscione et al., 1998; Nanobashvili et al., 2004). Y5R KO mice display a reduced NPY-mediated inhibition of glutamatergic synaptic transmission and are therefore more susceptible to kainate-induced seizure mortality (Marsh et al., 1999; Baraban, 2004).
NPY receptors are G protein-coupled receptors (GPCRs) with seven transmembrane domains, acting preferentially via hetero-trimeric Gi/o proteins (Michel et al., 1998). They can trigger a variety of intracellular responses, including inhibition of adenylyl cyclase, regulation of potassium and calcium channels and activation of the mitogen-activated protein kinase (MAPK) cascade in some cell types (Howell et al., 2005; Lu et al., 2010; Thiriet et al., 2011; Shimada et al., 2012). Binding of the ligand to the receptor stabilizes an active receptor conformation, essential for inducing intracellular signal transduction. NPY binding modes vary with individual receptors, with different amino acids impacting anchoring, affinity and binding (Beck-Sickinger et al., 1994; Merten et al., 2007; Walther et al., 2012; Pedragosa-Badia et al., 2013; Kaiser et al., 2015; Yang et al., 2018). NPY peptides reach the receptors by lateral diffusion, after being pre-associated with the membrane through their C-terminal domain (Lerch et al., 2004; Thomas et al., 2005) that is also essential for the binding of NPY to specific receptors, in particular Y2 (BeckSickinger et al., 1994).

NPY receptors are predominantly expressed at the cell surface and sequence motifs essential for endoplasmic reticulum export and delivery to the membrane have been identified, particularly in the C-terminal portion of the protein (Walther et al., 2011, 2012). Y2Rs display desensitization (Ziffert et al., 2020a) but can undergo arrestin beta3-dependent and independent internalization only when exposed to high concentrations of agonist (Lundell et al., 2011; Walther et al., 2011). The low rate of Y2R internalization may depend on the presence of a $\mathrm{N}$-terminal extracellular domain rich in acidic/anionic residues (Parker et al., 2001; Gicquiaux et al., 2002).

\section{NPY AND EPILEPSY}

A consistent amount of data demonstrates the functional involvement of the NPY system in epilepsy. This statement is supported by two lines of evidence: (1) the epileptogenic process and epilepsy itself modify the expression pattern of the genes encoding NPY and its receptors; (2) acting as neuromodulators, NPY peptides control network excitability and homeostasis.

NPY expression is increased both in rodent and human hippocampal sections from temporal lobe epilepsy (TLE) surgical samples (Sperk et al., 1992; Furtinger et al., 2001), despite the strong loss of hilar GABAergic interneurons that physiologically express NPY. This is because the excitatory granule cells, which in epilepsy give rise to mossy fiber sprouting (MFS), have been demonstrated to ectopically produce and release NPY (Mathern et al., 1995; McCarthy et al., 1998). MFS, the aberrant sprouting of granular axons that recurrently innervate granule cell dendrites in the molecular layer generating an auto-excitatory loop (Figure 1B), is a marker of TLE, even if its pathophysiological role is still controversial (Cavarsan et al., 2018).

In patients with hippocampal sclerosis, another common pathological trait of TLE, a shift toward higher Y2 receptor density is observed in the CA1, CA3, in the hilar region and in the inner molecular layer of the hippocampus (Furtinger et al., 2001). This receptor up-regulation may support a persistent $Y 2 R$ 
signaling, because it has been recently shown that $\mathrm{Y} 1$, but not Y2, receptors are rapidly internalized and recycled after binding to their ligand (Ziffert et al., 2020a,b). As noted above, increased Y2Rs signaling may imply an anti-epileptic effect (El Bahh et al., 2005). In fact, $Y 2 R$ knockout mice are totally insensitive to the anti-epileptic actions of NPY, both in vitro and in vivo (Woldbye et al., 2005).

As opposed to Y2 receptor up-regulation in the epileptic hippocampus, it has been shown that $\mathrm{Y} 1$ receptor mRNA and binding actually decrease in kindled rats (Gobbi et al., 1998) and in intra-hippocampal kainate-treated mice (O'Loughlin et al., 2014). A reduced density of Y1Rs has been also demonstrated in human patients with hippocampal sclerosis, indicating a reduced expression of the receptor or a loss of Y1R-expressing neurons (Kofler et al., 1997; Furtinger et al., 2001). In addition, as mentioned above, Y1Rs are rapidly internalized after binding to NPY (Ziffert et al., 2020a,b). Y1R may be responsible of unfavorable effects in epilepsy, because administration of Y1R antagonists produces antiepileptic effects in animal models (Gariboldi et al., 1998; Vezzani et al., 2000) and Y1 KO mice display reduced mortality rate upon NPY administration (Lin et al., 2006). Thus, their reduced density and signaling may be interpreted as an antiepileptic adaptive mechanism. It cannot be excluded, however, that this adaptive downregulation could be linked to epilepsy-induced depressive or anxious behavior, described in patients and in animal models (Yilmazer-Hanke et al., 2016; Vrinda et al., 2017; Zanirati et al., 2018).

Similarly, the decreased density of Y5R in epilepsy models (Bregola et al., 2000) may represent a maladaptive alteration because the pharmacological activation of Y5Rs has been reported to exert antiseizure effects (Woldbye et al., 1997).

Expression levels of NPY-related genes may strongly vary across species, with rats having higher expression of both NPY and Y2 compared to mice (Nadler et al., 2007; Károly et al., 2015). Discrepancy between rodents and humans have been also found at the electrophysiological level. In human slices, prepared from surgically resected hippocampi of drug-resistant patients, NPY application reduces both lateral perforant path-evoked excitatory response in granule cells (Patrylo et al., 1999) and currents evoked by medial perforant path stimulation (Ledri et al., 2015). Conversely, experiments on hippocampal slices from an animal model of epilepsy (pilocarpine-treated rats) show that NPY does not affect the response of granule cells to perforant path stimulation but reversibly inhibits recurrent synaptic transmission of mossy fibers on granule cells themselves ( $\mathrm{Tu}$ et al., 2005).

Even if the precise mechanism of action of the NPY system on the epileptic network has not been completely clarified, a clear effect of the neuropeptide in inhibiting epileptiform activity on human hippocampal sections challenged with $[0] \mathrm{Mg}^{2+} / 4$ amino-piridine has been demonstrated (Wickham et al., 2019), further corroborating the idea that the anti-epileptic effect is predominantly mediated by Y2. It has been shown indeed that the effect of NPY administration can be abolished by treatment with a specific Y2 receptor antagonist (Tu et al., 2005; Ledri et al., 2015; Wickham et al., 2019).
An epileptic insult in the brain can result in a synchronous activation of granule cells that fail to inhibit the propagation of excitation from the entorhinal cortex to the hippocampus. Subsequent compensation mechanisms might arise, and it is tempting to speculate that granule cells, with the death of their target inhibitory neurons, sprout their axons to the molecular layer, increasing excitability but, at the same time, producing synapses containing both NPY and Y2R at the presynaptic level. Within this view, NPY would act as a compensatory negative feedback, activated upon high frequency stimulation, where NPY is released from granular axons and reduce the overall hyperactivity of the local neuronal network. This hypothesis is also in line with the discrepancies that have been observed between mice and rats, with the latter showing higher recurrent mossy fiber sprouting and displaying higher levels of NPY and Y2 immunoreactivity coupled with a stronger inhibitory effect upon NPY application (Tu et al., 2005).

Taken together, these data suggest a significant involvement of NPY in the epileptogenic process, supporting the idea that both pharmacological and genetic approaches targeting the NPY system may represent effective strategies for the treatment of epilepsy. In the frame of this article, we will focus on the latter (gene therapies).

\section{EXPLOITING NPY IN GENE THERAPY}

In the last two decades, a great effort has been devoted to the development of gene therapy products for life-changing treatments in epilepsy. In that context, one of the most prominent strategies has been the direct infusion in epileptogenic areas of recombinant adeno-associated vectors (rAAVs) designed to modulate the NPY system (Table 1).

Early attempts in this direction explored the anti-seizure potential of NPY overexpression mediated by rAAV serotype 2 (rAAV2) vector injection in the hippocampus (Richichi et al., 2004) or piriform cortex (Foti et al., 2007) in the rat kainate model of epilepsy. Importantly, Richichi et al. (2004) compared the effects of serotypes AAV2 and chimeric AAV1/2, both vectors with the human NPY gene driven by the neuron-specific enolase promoter (pNSE). A long-term transgene expression, confined in hilar interneurons, was observed with AAV2, while more widespread expression in diverse subtypes of neurons was observed with the AAV1/2 serotype, that also conferred a more robust protection from epileptogenesis and chronic seizures. Y1 or Y2 double knockout mice, contrary to the wild type, did not display any protection from seizure activity upon NPY gene therapy, indicating that activation of one (most likely Y2) or both of these receptor subtypes was essential for the NPY effect (Lin et al., 2006). More recently, the AAV1/2 expressing-NPY vector was infused into the thalamus or somatosensory cortex in a rat model of genetic generalized epilepsy (GAERS, Genetic Absence Epileptic Rats from Strasbourg), resulting in a reduced seizure activity, in particular when injected in the thalamus (Powell et al., 2018).

Some concerns on the potential for translatability to human application were raised by Sørensen et al. (2008). These 
TABLE 1 | Comparison of different gene therapy strategies designed to modulate the NPY system, based on the use of recombinant adeno-associated vectors.

\begin{tabular}{|c|c|c|c|c|c|}
\hline First author (year) & Species & Model of epilepsy & Vector & $\begin{array}{l}\text { Time of vector } \\
\text { delivery }\end{array}$ & Transgene \\
\hline Richichi et al. (2004) & WT rats & $\begin{array}{l}\text { Intrahippocampal and } \\
\text { intracerebroventricular } \\
\text { kainic acid; } \\
\text { Kindling }\end{array}$ & $\begin{array}{l}\text { rAAV2_NSE-NPY; } \\
\text { rAAV1/2-NSE-NPY }\end{array}$ & Before seizure onset & Human pre-pro-NPY \\
\hline Lin et al. (2006) & $\begin{array}{l}\text { WT mice; } \\
\text { Y1 -/- and Y2 -/- mice }\end{array}$ & Systemic kainic acid & rAAV1/2_NSE-NPY & Before seizure onset & Human NPY cDNA \\
\hline Foti et al. (2007) & WT rats & $\begin{array}{l}\text { Intraperitoneal kainic } \\
\text { acid }\end{array}$ & $\begin{array}{l}\text { rAAV2_CBA-NPY; } \\
\text { rAAV2_CBA-NPY13-36 }\end{array}$ & Before seizure onset & $\begin{array}{l}\text { Full length and } \\
\text { NPY13-36 (Species not } \\
\text { specified) }\end{array}$ \\
\hline Sørensen et al. (2008) & WT rats & None & rAAV1/2_NSE-NPY & $\mathrm{N} / \mathrm{A}$ & Human pre-pro-NPY \\
\hline Noè et al. (2008) & WT rats & $\begin{array}{l}\text { Electrically induced } \\
\text { status epilepticus }\end{array}$ & rAAV1/2_CBA-NPY & After seizure onset & Human pre-pro-NPY \\
\hline Sørensen et al. (2009) & WT rats & Kindling & rAAV1/2_NSE-NPY & Before seizure onset & Human pre-pro-NPY \\
\hline Noè et al. (2010) & WT rats & $\begin{array}{l}\text { Intrahippocampal } \\
\text { kainic acid }\end{array}$ & $\begin{array}{l}\text { rAAV1_CBA-NPY; } \\
\text { rAAV1/2_CBA-NPY }\end{array}$ & After seizure onset & Human pre-pro-NPY \\
\hline Woldbye et al. (2010) & WT rats & $\begin{array}{l}\text { Kindling; } \\
\text { Subcutaneous } \\
\text { kainic acid }\end{array}$ & $\begin{array}{l}\text { rAAV1/2_NSE-NPY; } \\
\text { rAAV1/2_NSE-Y2 }\end{array}$ & After seizure onset & $\begin{array}{l}\text { Human pre-pro-NPY } \\
\text { Full length mouse } \\
\text { Y2 receptor }\end{array}$ \\
\hline Gøtzsche et al. (2012) & WT rats & $\begin{array}{l}\text { Subcutanous kainic } \\
\text { acid }\end{array}$ & $\begin{array}{l}\text { rAAV1/2_NSE-Y5; } \\
\text { rAAV1/2_NSE-NPY }\end{array}$ & Before seizure onset & $\begin{array}{l}\text { Human pre-pro-NPY } \\
\text { Full length mouse } \\
\text { Y5 receptor }\end{array}$ \\
\hline Olesen et al. (2012b) & WT mice & $\begin{array}{l}\text { Subcutaneous kainic } \\
\text { acid }\end{array}$ & rAAV1/2_NSE-Y1 & After seizure onset & $\begin{array}{l}\text { Full length mouse Y1 } \\
\text { receptor }\end{array}$ \\
\hline Olesen et al. (2012a) & WT mice & $\begin{array}{l}\text { Subcutaneous kainic } \\
\text { acid }\end{array}$ & rAAV1/2_NSE-Y5 & After seizure onset & $\begin{array}{l}\text { Full length mouse Y5 } \\
\text { receptor }\end{array}$ \\
\hline Dong et al. (2013) & WT rats & $\begin{array}{l}\text { Intrahippocampal } \\
\text { kainic acid }\end{array}$ & rAAV1/2_CMV-NPY & Before seizure onset & $\begin{array}{l}\text { Full length NPY } \\
\text { (species not specified) }\end{array}$ \\
\hline Zhang et al. (2013) & WT rats & $\begin{array}{l}\text { Intracerebroventricular } \\
\text { kainic acid }\end{array}$ & $\begin{array}{l}\text { rAAV1/2_NPY } \\
\text { (unknown promoter) }\end{array}$ & Before seizure onset & Not specified \\
\hline Nikitidou Ledri et al. (2016) & WT rats & $\begin{array}{l}\text { Intrahippocampal } \\
\text { kainic acid }\end{array}$ & $\begin{array}{l}\text { rAAV1/2_NSE-NPY; } \\
\text { rAAV1/2_NSE-Y2 }\end{array}$ & Before seizure onset & $\begin{array}{l}\text { Human pre-pro-NPY } \\
\text { Full length mouse } \\
\text { Y2 receptor }\end{array}$ \\
\hline Powell et al. (2018) & $\begin{array}{l}\text { GAERS (Genetic } \\
\text { Absence Epilepsy Rats) }\end{array}$ & None & rAAV1/2_NSE-NPY & $\mathrm{N} / \mathrm{A}$ & Human pre-pro-NPY \\
\hline Melin et al. (2019) & WT rats & $\begin{array}{l}\text { Intrahippocampal } \\
\text { kainic acid }\end{array}$ & rAAV1_CAG-NPY/Y2 & Before seizure onset & $\begin{array}{l}\text { Human pre-pro-NPY } \\
\text { Human Y2 receptor }\end{array}$ \\
\hline
\end{tabular}

authors claimed an impairment of synaptic plasticity and the attenuation of long-term potentiation of Schaffer collateral-CA1 synapses in naive rats upon unilateral vector injection in the hippocampus, with consequent deficits of hippocampal-based spatial discrimination learning (Sørensen et al., 2008). These unexpected findings were contrasted by the authors themselves in a following study that showed seizure protection with no impact on working memory performance tasks in kindled rats injected in both hippocampi with the AAV1/2-pNSE-NPY vector (Sørensen et al., 2009).

In any event, the initial attempts of NPY gene therapy had limited relevance for clinical translation: they were all carried out before epilepsy onset, in a scenario that is obviously nonreproducible in real patients and that did not take into account the aberrant changes occurring during epileptogenesis, which may significantly affect treatment effectiveness. In order to overcome this limitation, Noè et al. (2008) tested the effect of hippocampal injection of an AAV1/2 vector expressing NPY after the establishment of epilepsy in rats and found a decrease in seizure activity. Interestingly, this study also demonstrated preserved levels of Y2R into the AAV-injected hippocampus, with functional transport and high levels of release of the recombinant NPY to nerve terminals upon induction of neuronal depolarization. In a following report, the same authors delivered NPY using rAAV1, and observed a widespread transgene expression pattern throughout the injected hippocampi and a potent effect on seizure reduction, with no detectable evidence of immune response or cognitive impairment (Noè et al., 2010).

NPY is directly involved in the regulation of brain excitability by regulation of intracellular calcium and glutamate release, mainly through binding to and activation of Y1, Y2, and Y5 
receptors (Berglund et al., 2003). As described above, whereas converging evidence supports an anti-epileptic role of Y2 (and to a lesser extent of Y5) receptors, the involvement of Y1Rs remains debated, with some evidence of pro-epileptic effects. Therefore, a simple increase in NPY levels may become a double-edged sword.

These considerations prompted alternative gene therapy strategies, oriented not only at increasing NPY secretion into the epileptic focus but, also, at re-shaping the NPY ligand-receptor system by the delivery of genes encoding for the different NPY receptors. To date, the only study performed to evaluate the effects of a brain overexpression of Y1 in an animal model of epilepsy indicates an increased susceptibility to kainate-induced seizures (Olesen et al., 2012b), consistent with the mentioned evidence of Y1R-mediated pro-epileptic effects (Gariboldi et al., 1998; Benmaamar et al., 2003). One study proved seizure reduction through the delivery in the rat hippocampus of an AAV pool of vectors for the concomitant expression of both Y5 and NPY (Gøtzsche et al., 2012), but no protective effect was observed with the AAV-Y5 vector alone (Gøtzsche et al., 2012; Olesen et al., 2012a). More robust and promising data have been obtained by overexpressing Y2 receptors, i.e., by seconding the adaptive up-regulation of these receptors observed in the epileptic tissue. Y2Rs proved to be sufficient to suppress acute seizures even when overexpressed alone, although the therapeutic outcome significantly increased in the case of concurrent treatment with an NPY expressing vector (Woldbye et al., 2010).

Attempts of combinatorial gene delivery have been accomplished by using two separate rAAV vectors (Nikitidou Ledri et al., 2016). This procedure, however, faces some limitations, such as an unknown transduction efficiency of the different vectors upon brain infusion or the potential obstacles that a heterogeneous viral pool could face in case of clinical application. In order to solve such issues, Melin et al. (2019) used an AAV1-based vector specially designed for the concurrent expression of both NPY and Y2 from a single viral construct, injected into both dorsal and ventral hippocampus to target the epileptogenic focus. This dual-gene vector delivery led to a detectable overexpression of both NPY and Y2R within the injected hippocampi, particularly pronounced into the dorsal CA1 and CA3 regions, and resulted in a remarkable decrease of EEG seizure frequency and duration in the kainic acid model of TLE (Melin et al., 2019).

\section{PROBLEMS AND OPPORTUNITIES}

As described above, both NPY and its receptors display a high degree of complexity, from synthesis, processing and compartmentalized delivery or regulated secretion, to an intricated variety of biological effects, both at local and global circuit level. These elements have profound implications for gene therapy.

The majority of data reported in the literature derive from experiments performed with viral vectors constructed to express pre-pro-NPY (Table 1). In this context, the use of the full length NPY sequence may be advantageous, since it allows using the endogenous cellular machinery to process and pack the propeptide into vesicles, where the mature NPY is formed and then stored. In this way stimulus-dependent release of the peptide (e.g., at the onset of a seizure) can be preserved. Biosynthesis and stimulus-dependent release of mature NPY have been indeed shown ex vivo (Noè et al., 2008). While all this may occur in cells that physiologically express NPY, NPY gene delivery alone may not be sufficient for regulated release of the mature peptide in cells lacking/under-expressing one or more of the regulatory elements (e.g., processing enzymes, trafficking proteins) needed in such a complex multi-step system. One option to circumvent this problem could be linking the NPY gene sequence to the sequence of the laminar protein fibronectin (FIB), which induces a constitutive secretion as opposed to a regulated secretion (Foti et al., 2007). Finally, even after release, the effects of peptidases should be taken into account to understand and modulate NPY signaling.

The modulation of YRs expression requires an even more finely regulated sequence of events. Functional specificity of the NPY system depends largely on receptors. In this context, the processes of anterograde transport, internalization, recycling or degradation have been thoroughly characterized for only a few NPY receptors. These considerations lead to the suggestion that, if no specific cell targeting strategy is employed, gene therapyinduced overexpression of NPY or NPY receptors may be more efficient in (or even restricted to) cells that physiologically or pathophysiologically express them. The levels of released NPY and the coupling between ligand and receptor are also crucial for inducing the desired effect in the right cell target. It may be possible to obtain a certain degree of receptor selectivity by using, for example, N-terminally truncated forms of NPY (like NPY $3-36$ or NPY $13-36$ (Beck-Sickinger and Jung, 1995; Sajdyk et al., 2002; Foti et al., 2007; Pedragosa-Badia et al., 2013) that could favor Y2Rs dependent signaling.

\section{OUTLOOK FOR HUMAN STUDIES USING VIRAL VECTOR-BASED STRATEGIES}

Despite this complexity, several anti-epileptic gene therapy strategies proved successful in modulating the inhibitory/excitatory balance within animal brain regions involved in seizure onset by focal overexpression of NPY alone or in combination with Y2 or Y5 receptors. Even if extended long-time studies to exclude side effects or neuropathological changes due to application of viral vectors still need to be performed (optimally in non-human primates), these compelling preclinical data may concretely prompt the design of a first-inhuman gene therapy trial in drug-resistant epileptic patients. As an example, patients deemed suitable for surgical resection of a clearly mapped epileptogenic region may be enrolled in a first putative human study. This would allow to design a confined (and presumably more effective) transgene expression within the epileptogenic lesion only, while preserving the unaffected brain tissue and thereby lowering the risk of unpredictable side effects. In addition, should the treatment not prove to be effective or well-tolerated, patients would undergo resective surgery as originally planned.

Several issues should be taken into account in the study design. For example, hippocampal sclerosis, if extensive, may reduce vector diffusion and transduction efficacy, imposing 
a personalization of the dose. The choice of vector would largely depend on the strategy employed to regulate the expression of the therapeutic gene. As described in this review, all studies on gene therapy-mediated overexpression of NPY and/or its receptors in epilepsy models have been performed by using AAV vectors. However, the limited cargo capacity of AAVs may hinder their adaptability for clinical translation, in particular when complex regulatory mechanisms must be set in place. In fact, it would be desirable to regulate the levels of transgene expression in a patient-tailored manner, in response to endogenous and/or exogenous clues. While an endogenous control of the transgene expression system that responds to physiological stimuli (for example, glutamate accumulation) would be preferable, the time needed for the biosynthesis and delivery of the therapeutic protein(s) would be too long to arrest an ongoing seizure. Therefore, a more concrete alternative, although not applicable to the response to individual seizures, but rather on a general control of seizure threshold, may rely on the administration of external factors (i.e., specific molecules). These elements could selectively activate or inhibit transgene expression, by acting on specific regulatory sequences delivered along with the therapeutic gene cassette, in the same viral

\section{REFERENCES}

Abid, K., Rochat, B., Lassahn, P. G., Stöcklin, R., Michalet, S., Brakch, N., et al. (2009). Kinetic study of neuropeptide Y (NPY) proteolysis in blood and identification of NPY3-35. A new peptide generated by plasma kallikrein. J. Biol. Chem. 284, 24715-24724. doi: 10.1074/jbc.M109. 035253

Aicher, S. A., Springston, M., Berger, S. B., Reis, D. J., and Wahlestedt, C. (1991). Receptor-selective analogs demonstrate NPY/PYY receptor heterogeneity in rat brain. Neurosci. Lett. 130, 32-36. doi: 10.1016/0304-3940(91) 90220-N

Allen, J., Novotny, J., Martin, J., and Heinrich, G. (1987). Molecular structure of mammalian neuropeptide $\mathrm{Y}$ : analysis by molecular cloning and computer-aided comparison with crystal structure of avian homologue. Proc. Natl. Acad. Sci. U. S. A. $84,2532-2536$. doi: $10.1073 /$ pnas.84.8.2532

Atanasova, K. R., and Reznikov, L. R. (2018). Neuropeptides in asthma, chronic obstructive pulmonary disease and cystic fibrosis. Respir. Res. 19:149. doi: 10.1186/s12931-018-0846-4

Baldock, P. A., Allison, S. J., Lundberg, P., Lee, N. J., Slack, K., Lin, E. J. D., et al. (2007). Novel role of Y1 receptors in the coordinated regulation of bone and energy homeostasis. J. Biol. Chem. 282, 19092-19102. doi: 10.1074/jbc.M700644200

Baraban, S. C. (2004). Neuropeptide Y and epilepsy: recent progress, prospects and controversies. Neuropeptides 38, 261-265. doi: 10.1016/j.npep.2004.04.006

Beck-Sickinger, A. G., and Jung, G. (1995). Structure-activity relationships of neuropeptide $\mathrm{Y}$ analogues with respect to $\mathrm{Y} 1$ and $\mathrm{Y} 2$ receptors. Biopolymers 37, 123-142. doi: 10.1002/bip.360370207

Beck-Sickinger, A. G., Weland, H. A., Wittneben, H., Willim, K. -D, Rudolf, K., and Jung, G. (1994). Complete L-alanine scan of neuropeptide Y reveals ligands binding to Y1 and Y2 receptors with distinguished conformations. Eur. J. Biochem. 225, 947-958. doi: 10.1111/j.1432-1033.1994.0947b.x

Benarroch, E. E. (2009). Neuropeptide Y: its multiple effects in the CNS and potential clinical significance. Neurology 72, 1016-1020. doi: 10.1212/01.wnl.0000345258.18071.54

Benmaamar, R., Pham-Lê, B. T., Marescaux, C., Pedrazzini, T., and Depaulis, A. (2003). Induced down-regulation of neuropeptide Y-Y1 receptors delays initiation of kindling. Eur. J. Neurosci. 18, 768-774. doi: 10.1046/j.1460-9568.2003.02810.x vector. This option, however, would require the exploitation of neurotropic vectors capable to host much larger exogenous DNA cargos, for example HSV derived vectors (Ingusci et al., 2019a,b).

Once the remaining gaps in knowledge and hurdles for gene therapy will be overcome, we may finally be able to treat epilepsy by acting on endogenous systems of neuromodulation. In a way, this is something that we may have already done, unconsciously and much less finely, with certain anti-epileptic drugs (Brill et al., 2006).

\section{AUTHOR CONTRIBUTIONS}

All authors listed have made a substantial, direct and intellectual contribution to the work, and approved it for publication.

\section{FUNDING}

This work was supported by a grant from the European Community [FP7-HEALTH project 602102 (EPITARGET)].

Berglund, M. M., Hipskind, P. A., and Gehlert, D. R. (2003). Recent developments in our understanding of the physiological role of PP-fold peptide receptor subtypes. Exp. Biol. Med. 228, 217-244. doi: 10.1177/1535370203228 00301

Bregola, G., Dumont, Y., Fournier, A., Zucchini, S., Quirion, R., and Simonato, M. (2000). Decreased levels of neuropeptide Y5 receptor binding sites in two experimental models of epilepsy. Neuroscience 98, 697-703. doi: 10.1016/S0306-4522(00)00162-7

Brill, J., Lee, M., Zhao, S., Fernald, R. D., and Huguenard, J. R. (2006). Chronic valproic acid treatment triggers increased neuropeptide $\mathrm{Y}$ expression and signaling in rat nucleus reticularis thalami. J. Neurosci. 26, 6813-6822. doi: 10.1523/JNEUROSCI.5320-05.2006

Brumovsky, P. R., Shi, T. J., Matsuda, H., Kopp, J., Villar, M. J., and Hökfelt, T. (2002). NPY Y1 receptors are present in axonal processes of DRG neurons. Exp. Neurol. 174, 1-10. doi: 10.1006/exnr.2001.7845

Caberlotto, L. (1997). Localization of neuropeptide Y Y1 mRNA in the human brain: abundant expression in cerebral cortex and striatum. Eur. J. Neurosci. 9, 1212-1225. doi: 10.1111/j.1460-9568.1997.tb01476.x

Cabrele, C., and Beck-Sickinger, A. G. (2000). Molecular characterization of the ligand-receptor interaction of the neuropeptide Y family. J. Pept. Sci. 6, 97-122. doi: 10.1002/(SICI)1099-1387(200003)6:3<97::AID-PSC236>3. $0 . \mathrm{CO} ; 2-\mathrm{E}$

Castan, I., Valet, P., Larrouy, D., Voisin, T., Remaury, A., Daviaud, D., et al. (1993). Distribution of PYY receptors in human fat cells: an antilipolytic system alongside the $\alpha 2$-adrenergic system. Am. J. Physiol. 265(1 Pt 1), E74-E80. doi: 10.1152/ajpendo.1993.265.1.E74

Cavarsan, C. F., Malheiros, J., Hamani, C., Najm, I., and Covolan, L. (2018). Is mossy fiber sprouting a potential therapeutic target for epilepsy? Front. Neurol. 9:1023. doi: 10.3389/fneur.2018.01023

Cerdá-Reverter, J. M., and Larhammar, D. (2000). cNeuropeptide Y family of peptides: Structure, anatomical expression, function, and molecular evolution. Biochem. Cell Biol. 78, 371-392. doi: 10.1139/o00-004

Chronwall, B. M., DiMaggio, D. A., Massari, V. J., Pickel, V. M., Ruggiero, D. A., and O'donohue, T. L. (1985). The anatomy of neuropeptide$\mathrm{y}$-containing neurons in rat brain. Neuroscience 15, 1159-1181. doi: 10.1016/0306-4522(85)90260-X

Colmers, W. F., Klapstein, G. J., Fournier, A., St-Pierre, S., and Treherne, K. A. (1991). Presynaptic inhibition by neuropeptide Y in rat hippocampal 
slice in vitro is mediated by a Y2 receptor. Br. J. Pharmacol. 102, 41-44. doi: 10.1111/j.1476-5381.1991.tb12129.x

Colmers, W. F., Lukowiak, K., and Pittman, Q. J. (1985). Neuropeptide $\mathrm{Y}$ reduces orthodromically evoked population spike in rat hippocampal CA1 by a possibly presynaptic mechanism. Brain Res. 346, 404-408. doi: 10.1016/0006-8993(85)90880-7

Colmers, W. F., Lukowiak, K., and Pittman, Q. J. (1987). Presynaptic action of neuropeptide Y in area CA1 of the rat hippocampal slice. J. Physiol. 383, 285-299. doi: 10.1113/jphysiol.1987.sp016409

Colmers, W. F., Lukowiak, K., and Pittman, Q. J. (1988). Neuropeptide Y action in the rat hippocampal slice: site and mechanism of presynaptic inhibition. J. Neurosci. 8, 3827-3837. doi: 10.1523/JNEUROSCI.08-10-03827.1988

Criscione, L., Rigollier, P., Batzl-Hartmann, C., Rüeger, H., Stricker-Krongrad, A., Wyss, P., et al. (1998). Food intake in free-feeding and energy-deprived lean rats is mediated by the neuropeptide Y5 receptor. J. Clin. Invest. 102, 2136-2145. doi: $10.1172 / \mathrm{JCI} 4188$

De Jong-Brink, M., Ter Maat, A., and Tensen, C. P. (2001). NPY in invertebrates: Molecular answers to altered functions during evolution. Peptides 22, 309-315. doi: 10.1016/S0196-9781(01)00332-1

de Quidt, M. E., and Emson, P. C. (1986). Distribution of neuropeptide Y-like immunoreactivity in the rat central nervous system-II. Immunohistochemical analysis. Neuroscience 18, 545-618. doi: 10.1016/0306-4522(86) 90057-6

Dong, C., Zhao, W., Li, W., Lv, P., and Dong, X. (2013). Anti-epileptic effects of neuropeptide Y gene transfection into the rat brain. Neural Regen. Res. 8, 1307-1315. doi: 10.3969/j.issn.1673-5374.2013.14.007

Dum, E., Fürtinger, S., Gasser, E., Bukovac, A., Drexel, M., Tasan, R., et al. (2017). Effective G-protein coupling of Y2 receptors along axonal fiber tracts and its relevance for epilepsy. Neuropeptides 61, 49-55. doi: 10.1016/j.npep.2016.10.005

Dumont, Y., Fournier, A., St-Pierre, S., and Quirion, R. (1993). Comparative characterization and autoradiographic distribution of neuropeptide Y receptor subtypes in the rat brain. J. Neurosci. 13, 73-86. doi: 10.1523/JNEUROSCI.13-01-00073.1993

Dumont, Y., Fournier, A., St-Pierre, S., Schwartz, T. W., and Quirion, R. (1990). Differential distribution of neuropeptide Y1 and Y2 receptors in the rat brain. Eur. J. Pharmacol. 191, 501-503. doi: 10.1016/0014-2999(90) 94189-5

Dumont, Y., Jacques, D., Bouchard, P., and Quirion, R. (1998). Species differences in the expression and distribution of the neuropeptide $\mathrm{Y}$ Y1, Y2, Y4, and $\mathrm{Y} 5$ receptors in rodents, guinea pig, and primates brains. J. Comp. Neurol. 402, 372-384. doi: 10.1002/(SICI) 1096-9861(19981221)402:3<372::AID-CNE6>3.0.CO;2-2

Dumont, Y., Martel, J. C., Fournier, A., St-Pierre, S., and Quirion, R. (1992). Neuropeptide $\mathrm{Y}$ and neuropeptide $\mathrm{Y}$ receptor subtypes in brain and peripheral tissues. Prog. Neurobiol. 38, 125-167. doi: 10.1016/0301-0082(92)90038-G

El Bahh, B., Balosso, S., Hamilton, T., Herzog, H., Beck-Sickinger, A. G., Sperk, G., et al. (2005). The anti-epileptic actions of neuropeptide $\mathrm{Y}$ in the hippocampus are mediated by Y2 and not Y5 receptors. Eur. J. Neurosci. 22, 1417-1430. doi: 10.1111/j.1460-9568.2005.04338.x

El Bahh, B., Cao, J. Q., Beck-Sickinger, A. G., and Colmers, W. F. (2002). Blockade of neuropeptide Y2 receptors and suppression of NPY's anti-epileptic actions in the rat hippocampal slice by BIIE0246. Br. J. Pharmacol. 136, 502-509. doi: $10.1038 /$ sj.bjp. 0704751

Elfvin, L. G., Holmberg, K., Emson, P., Schemann, M., and Hökfelt, T. (1997). Nitric oxide synthase, choline acetyltransferase, catecholamine enzymes and neuropeptides and their colocalization in the anterior pelvic ganglion, the inferior mesenteric ganglion and the hypogastric nerve of the male guinea pig. J. Chem. Neuroanat. 14, 33-49. doi: 10.1016/S0891-0618(97)10010-2

Flood, J. F., and Morley, J. E. (1989). Dissociation of the effects of neuropeptide $\mathrm{Y}$ on feeding and memory: Evidence for pre- and postsynaptic mediation. Peptides 10, 963-966. doi: 10.1016/0196-9781(89)90176-9

Foti, S., Haberman, R. P., Samulski, R. J., and McCown, T. J. (2007). Adenoassociated virus-mediated expression and constitutive secretion of NPY or NPY13-36 suppresses seizure activity in vivo. Gene Ther. 14, 1534-1536. doi: 10.1038/sj.gt.3303013

Furtinger, S., Pirker, S., Czech, T., Baumgartner, C., Ransmayr, G., and Sperk, G. (2001). Plasticity of Y1 and Y2 receptors and neuropeptide Y fibers in patients with temporal lobe epilepsy. J. Neurosci. 21, 5804-5812. doi: 10.1523/JNEUROSCI.21-15-05804.2001

Gariboldi, M., Conti, M., Cavaleri, D., Samanin, R., and Vezzani, A. (1998). Anticonvulsant properties of BIBP3226, a non-peptide selective antagonist at neuropeptide Y Y1 receptors. Eur. J. Neurosci. 10, 757-759. doi: 10.1046/j.1460-9568.1998.00061.x

Gehlert, D. R., Gackenheimer, S. L., and Schober, D. A. (1992). [Leu31-Pro34] neuropeptide Y identifies a subtype of 125I-labeled peptide YY binding sites in the rat brain. Neurochem. Int. 21, 45-67. doi: 10.1016/0197-0186(92)90067-2

Gerald, C., Walker, M. W., Criscione, L., Gustafson, E. L., Batzl-Hartmann, C., Smith, K. E., et al. (1996). A receptor subtype involved in neuropeptide-Yinduced food intake. Nature 382, 168-171. doi: 10.1038/382168a0

Gershkovich, M. M., Groß, V. E., Kaiser, A, and Prömel, S. (2019). Pharmacological and functional similarities of the human neuropeptide $\mathrm{Y}$ system in C. elegans challenges phylogenetic views on the FLP/NPR system. Cell Commun. Signal 17, 123-123. doi: 10.1186/s12964-019-0436-1

Gicquiaux, H., Lecat, S., Gaire, M., Dieterlen, A., Mély, Y., Takeda, K., et al. (2002). Rapid internalization and recycling of the human neuropeptide Y Y1 receptor. J. Biol. Chem. 277, 6645-6655. doi: 10.1074/jbc.M107224200

Giesbrecht, C. J., Mackay, J. P., Silveira, H. B., Urban, J. H., and Colmers, W. F. (2010). Countervailing modulation of Ihby neuropeptide $\mathrm{Y}$ and corticotrophinreleasing factor in basolateral amygdala as a possible mechanism for their effects on stress-related behaviors. J. Neurosci. 30, 16970-16982. doi: 10.1523/JNEUROSCI.2306-10.2010

Glass, M. J., Chan, J., and Pickel, V. M. (2002). Ultrastructural localization of neuropeptide Y Y1 receptors in the rat medial nucleus tractus solitarius: relationships with neuropeptide $\mathrm{Y}$ or catecholamine neurons. J. Neurosci. Res. 67, 753-765. doi: 10.1002/jnr.10185

Gobbi, M., Gariboldi, M., Piwko, C., Hoyer, D., Sperk, G., and Vezzani, A. (1998). Distinct changes in peptide YY binding to, and mRNA levels of, $\mathrm{Y} 1$ and $\mathrm{Y} 2$ receptors in the rat hippocampus associated with kindling epileptogenesis. J. Neurochem. 70, 1615-1622. doi: 10.1046/j.1471-4159.1998.70041615.x

Gøtzsche, C. R., Nikitidou, L., Sørensen, A. T., Olesen, M. V., Sørensen, G., Christiansen, S. H. O., et al. (2012). Combined gene overexpression of neuropeptide $\mathrm{Y}$ and its receptor $\mathrm{Y} 5$ in the hippocampus suppresses seizures. Neurobiol. Dis. 45, 288-296. doi: 10.1016/j.nbd.2011.08.012

Grandt, D., Schimiczek, M., Rascher, W., Feth, F., Shively, J., Lee, T. D., et al. (1996). Neuropeptide Y 3-36 is an endogenous ligand selective for Y2 receptors. Regul. Pept. 67, 33-37. doi: 10.1016/S0167-0115(96)00104-8

Greber, S., Schwarzer, C., and Sperk, G. (1994). Neuropeptide Y inhibits potassiumstimulated glutamate release through Y2 receptors in rat hippocampal slices in vitro. Br. J. Pharmacol. 113, 737-740. doi: 10.1111/j.1476-5381.1994.tb17055.x

Guo, H. U. I., Castro, P. A., Palmiter, R. D., and Baraban, S. C. (2002). Y5 receptors mediate neuropeptide $\mathrm{Y}$ actions at excitatory synapses in area $\mathrm{CA} 3$ of the mouse hippocampus. J. Neurophysiol. 87, 558-566. doi: 10.1152/jn.00532.2001

Howell, O. W., Doyle, K., Goodman, J. H., Scharfman, H. E., Herzog, H., Pringle, A., et al. (2005). Neuropeptide Y stimulates neuronal precursor proliferation in the post-natal and adult dentate gyrus. J. Neurochem. 93, 560-570. doi: 10.1111/j.1471-4159.2005.03057.x

Hubers, S. A., Wilson, J. R., Yu, C., Nian, H., Grouzmann, E., Eugster, P., et al. (2018). DPP (dipeptidyl peptidase)-4 inhibition potentiates the vasoconstrictor response to NPY (neuropeptide Y) in humans during renin-angiotensin-aldosterone system inhibition. Hypertension 72, 712-719. doi: 10.1161/HYPERTENSIONAHA.118.11498

Ingusci, S., Cattaneo, S., Verlengia, G., Zucchini, S., and Simonato, M. (2019a). A matter of genes: the hurdles of gene therapy for epilepsy. Epilepsy Curr. 19, 38-43. doi: 10.1177/1535759718822846

Ingusci, S., Verlengia, G., Soukupova, M., Zucchini, S., and Simonato, M. (2019b). Gene therapy tools for brain diseases. Front. Pharmacol. 10:724. doi: 10.3389/fphar.2019.00724

Jacques, D., Dumont, Y., Fournier, A., and Quirion, R. (1997). Characterization of neuropeptide $\mathrm{Y}$ receptor subtypes in the normal human brain, including the hypothalamus. Neuroscience 79, 129-148. doi: 10.1016/S0306-4522(96) 00639-2

Kaiser, A., Müller, P., Zellmann, T., Scheidt, H. A., Thomas, L., Bosse, M., et al. (2015). Unwinding of the C-terminal residues of neuropeptideY is critical for Y2 receptor binding and activation. Angew. Chem. Int. Ed. 54, 7446-7449. doi: 10.1002/anie.201411688 
Károly, N., Dobó, E. A., and Mihály, A. (2015). Comparative immunohistochemical study of the effects of pilocarpine on the mossy cells, mossy fibres and inhibitory neurones in murine dentate gyrus. Acta Neurobiol. Exp. 75, 220-237.

Keast, J. R. (1991). Patterns of co-existence of peptides and differences of nerve fibre types associated with noradrenergic and non-noradrenergic (putative cholinergic) neurons in the major pelvic ganglion of the male rat. Cell Tissue Res. 266, 405-415. doi: 10.1007/BF00318197

Klapstein, G. J., and Colmers, W. F. (1992). 4-Aminopyridine and low Ca2+ differentiate presynaptic inhibition mediated by neuropeptide $\mathrm{Y}$, baclofen and 2-chloroadenosine in rat hippocampal CA1 in vitro. Br. J. Pharmacol. 105, 470-474. doi: 10.1111/j.1476-5381.1992.tb14277.x

Klapstein, G. J., and Colmers, W. F. (1993). On the sites of presynaptic inhibition by neuropeptide $\mathrm{y}$ in rat hippocampus in vitro. Hippocampus 3, 103-111. doi: 10.1002/hipo.450030111

Klapstein, G. J., and Colmers, W. F. (1997). Neuropeptide Y suppresses epileptiform activity in rat hippocampus in vitro. J. Neurophysiol. 78, 1651-1661. doi: 10.1152/jn.1997.78.3.1651

Kofler, N., Kirchmair, E., Schwarzer, C., and Sperk, G. (1997). Altered expression of NPY-Y1 receptors in kainic acid induced epilepsy in rats. Neurosci. Lett. 230, 129-132. doi: 10.1016/S0304-3940(97)00492-8

Kooijman, S. A. L. M., and Troost, T. A. (2007). Quantitative steps in the evolution of metabolic organisation as specified by the dynamic energy budget theory. Biol. Rev. 82, 113-42. doi: 10.1111/j.1469-185X.2006.00006.x

Kopp, J., Xu, Z. Q., Zhang, X., Pedrazzini, T., Herzog, H., Kresse, A., et al. (2002). Expression of the neuropeptide Y Y1 receptor in the CNS of rat and of wild-type and Y1 receptor knock-out mice. Focus on immunohistochemical localization. Neuroscience 111, 443-532. doi: 10.1016/S0306-4522(01)00463-8

Kuo, L. E., Kitlinska, J. B., Tilan, J. U., Li, L., Baker, S. B., Johnson, M. D., et al. (2007). Neuropeptide Y acts directly in the periphery on fat tissue and mediates stress-induced obesity and metabolic syndrome. Nat. Med. 13, 803-811. doi: 10.1038/nm1611

Larhammar, D., and Salaneck, E. (2004). Molecular evolution of NPY receptor subtypes. Neuropeptides 38, 141-51. doi: 10.1016/j.npep.2004.06.002

Leblanc, G. G., Trimmer, B. A., and Landis, S. C. (1987). Neuropeptide Y-like immunoreactivity in rat cranial parasympathetic neurons: coexistence with vasoactive intestinal peptide and choline acetyltransferase. Proc. Natl. Acad. Sci. U. S. A. 84, 3511-3515. doi: 10.1073/pnas.84.10.3511

Ledri, M., Sørensen, A. T., Madsen, M. G., Christiansen, S. H., Ledri, L. N., Cifra, A., et al. (2015). Differential effect of neuropeptides on excitatory synaptic transmission in human epileptic hippocampus. J. Neurosci. 35, 9622-31. doi: 10.1523/JNEUROSCI.3973-14.2015

Lerch, M., Mayrhofer, M., and Zerbe, O. (2004). Structural similarities of micelle-bound peptide YY (PYY) and neuropeptide Y (NPY) are related to their affinity profiles at the Y receptors. J. Mol. Biol. 339, 1153-1168. doi: 10.1016/j.jmb.2004.04.032

Li, Q., Bartley, A. F., and Dobrunz, L. E. (2017). Endogenously released neuropeptide $\mathrm{Y}$ suppresses hippocampal short-term facilitation and is impaired by stress-induced anxiety. J. Neurosci. 37:23-37. doi: 10.1523/JNEUROSCI.2599-16.2017

Lin, E. J., Young, D., Baer, K., Herzog, H., and During, M. J. (2006). Differential actions of NPY on seizure modulation via Y1 and Y2 receptors: evidence from receptor knockout mice. Epilepsia 47, 773-780. doi: 10.1111/j.1528-1167.2006.00500.x

Lindner, D., Stichel, J., and Beck-Sickinger, A. G. (2008). Molecular recognition of the NPY hormone family by their receptors. Nutrition 24, 907-917. doi: 10.1016/j.nut.2008.06.025

Lu, C., Everhart, L., Tilan, J., Kuo, L., Sun, C. C. J., Munivenkatappa, R. B., et al. (2010). Neuropeptide y and its Y2 receptor: potential targets in neuroblastoma therapy. Oncogene 29, 5630-5642. doi: 10.1038/onc.2010.301

Lundberg, J. M., Rudehill, A., Sollevi, A., Theodorsson-Norheim, E., and Hamberger, B. (1986). Frequency- and reserpine-dependent chemical coding of sympathetic transmission: differential release of noradrenaline and neuropeptide Y from pig spleen. Neurosci. Lett. 63, 96-100. doi: 10.1016/0304-3940(86)90020-0

Lundell, I., Rabe Bernhardt, N., Johnsson, A. K., and Larhammar, D. (2011). Internalization studies of chimeric neuropeptide $\mathrm{Y}$ receptors $\mathrm{Y} 1$ and $\mathrm{Y} 2$ suggest complex interactions between cytoplasmic domains. Regul. Pept. 168, 50-8. doi: 10.1016/j.regpep.2011.03.004

Marsh, D. J., Baraban, S. C., Hollopeter, G., and Palmiter, R. D. (1999). Role of the Y5 neuropeptide Y receptor in limbic seizures. Proc. Natl. Acad. Sci. U. S. A. 96, 13518-13523. doi: 10.1073/pnas.96.23.13518

Martire, M., Pistritto, G., Mores, N., Agnati, L. F., and Fuxe, K. (1993). Region-specific inhibition of potassium-evoked [3H]noradrenaline release from rat brain synaptosomes by neuropeptide Y-(13-36). Involvement of NPY receptors of the Y2 type. Eur. J. Pharmacol. 230, 231-234. doi: 10.1016/0014-2999(93)90807-T

Mathern, G. W., Babb, T. L., Pretorius, J. K., and Leite, J. P. (1995). Reactive synaptogenesis and neuron densities for neuropeptide $\mathrm{Y}$, somatostatin, and glutamate decarboxylase immunoreactivity in the epileptogenic human fascia dentata. J. Neurosci. 15, 3990-4004. doi: 10.1523/JNEUROSCI.15-05-03990.1995

McCarthy, J. B., Walker, M., Pierce, J., Camp, P., and White, J. D. (1998). Biosynthesis and metabolism of native and oxidized neuropeptide $\mathrm{Y}$ in the hippocampal mossy fiber system. J. Neurochem. 70, 1950-1963. doi: 10.1046/j.1471-4159.1998.70051950.x

Mcquiston, A. R., and Colmers, W. F. (1996). Neuropeptide Y2 receptors inhibit the frequency of spontaneous but not miniature EPSCS in CA3 pyramidal cells of rat hippocampus. J. Neurophysiol. 76, 3159-3168. doi: 10.1152/jn.1996.76.5.3159

Melin, E., Nanobashvili, A., Avdic, U., Gøtzsche, C. R., Andersson, M., Woldbye, D. P. D., et al. (2019). Disease modification by combinatorial single vector gene therapy: a preclinical translational study in epilepsy. Mol. Ther. Methods Clin. Dev. 15, 179-193. doi: 10.1016/j.omtm.2019.09.004

Merten, N., Lindner, D., Rabe, N., Römpler, H., Mörl, K., Schöneberg, T., et al. (2007). Receptor subtype-specific docking of Asp6.59 with C-terminal arginine residues in Y receptor ligands. J. Biol. Chem. 282, 7543-7551. doi: 10.1074/jbc.M608902200

Michel, M. C., Beck-Sickinger, A., Cox, H., Doods, H. N., Herzog, H., Larhammar, D., et al. (1998). XVI. International union of pharmacology recommendations for the nomenclature of neuropeptide $\mathrm{Y}$, peptide $\mathrm{YY}$, and pancreatic polypeptide receptors. Pharmacol. Rev. 50, 143-50.

Minth, C. D., Bloom, S. R., Polak, J. M., and Dixon, J. E. (1984). Cloning, characterization, and DNA sequence of a human cDNA encoding neuropeptide tyrosine. Proc. Natl. Acad. Sci. U. S. A. 81, 4577-4581. doi: 10.1073/pnas.81.14.4577

Mitchell, G. C., Wang, Q., Ramamoorthy, P., and Whim, M. D. (2008). A common single nucleotide polymorphism alters the synthesis and secretion of neuropeptide Y. J. Neurosci. 28, 14428-14434. doi: 10.1523/JNEUROSCI.0343-08.2008

Monnet, F. P., Fournier, A., Debonnel, G., and De Montigny, C. (1992). Neuropeptide $\mathrm{Y}$ potentiates selectively the $\mathrm{N}$-methyl-D-aspartate response in the rat CA3 dorsal hippocampus. I. Involvement of an atypical neuropeptide $\mathrm{Y}$ receptor. J. Pharmacol. Exp. Ther. 263, 1212-1218.

Nadler, J. V., Tu, B., Timofeeva, O., Jiao, Y., and Herzog, H. (2007). Neuropeptide $\mathrm{Y}$ in the recurrent mossy fiber pathway. Peptides 28, 357-364. doi: 10.1016/j.peptides.2006.07.026

Nanobashvili, A., Woldbye, D. P. D., Husum, H., Bolwig, T. G., and Kokaia, M. (2004). Neuropeptide Y Y5 receptors suppress in vitro spontaneous epileptiform bursting in the rat hippocampus. NeuroReport 15, 339-343. doi: 10.1097/00001756-200402090-00026

Nguyen, A. D., Mitchell, N. F., Lin, S., Macia, L., Yulyaningsih, E., Baldock, P. A., et al. (2012). Y1 and Y5 receptors are both required for the regulation of food intake and energy homeostasis in mice. PLOS ONE 7:e40191. doi: 10.1371/journal.pone.0040191

Nikitidou Ledri, L., Melin, E., Christiansen, S. H., Gøtzsche, C. R., Cifra, A., Woldbye, D. P. D., et al. (2016). Translational approach for gene therapy in epilepsy: model system and unilateral overexpression of neuropeptide Y and Y2 receptors. Neurobiol. Dis. 86, 52-61. doi: 10.1016/j.nbd.2015. 11.014

Noè, F., Pool, A. H., Nissinen, J., Gobbi, M., Bland, R., Rizzi, M., et al. (2008). Neuropeptide Y gene therapy decreases chronic spontaneous seizures in a rat model of temporal lobe epilepsy. Brain 131, 1506-1515. doi: 10.1093/brain/awn079 
Noè, F. M., Sørensen, A. T., Kokaia, M., and Vezzani, A. (2010). Gene therapy of focal-onset epilepsy by adeno-associated virus vector-mediated overexpression of neuropeptide y. Epilepsia 51, 96-96. doi: 10.1111/j.1528-1167.2010.02882.x

Olesen, M. V., Christiansen, S. H., Gøtzsche, C. R., Holst, B., Kokaia, M., and Woldbye, D. P. D. (2012a). Y5 neuropeptide Y receptor overexpression in mice neither affects anxiety- and depression-like behaviours nor seizures but confers moderate hyperactivity. Neuropeptides 46, 71-79. doi: 10.1016/j.npep.2012.01.002

Olesen, M. V., Christiansen, S. H., Gøtzsche, C. R., Nikitidou, L., Kokaia, M., and Woldbye, D. P. D. (2012b). Neuropeptide Y Y1 receptor hippocampal overexpression via viral vectors is associated with modest anxiolyticlike and proconvulsant effects in mice. J. Neurosci. Res. 90, 498-507. doi: 10.1002/jnr.22770

O'Loughlin, E. K., Pakan, J. M. P., McDermott, K. W., and YilmazerHanke, D. (2014). Expression of neuropeptide Y1 receptors in the amygdala and hippocampus and anxiety-like behavior associated with Ammon's horn sclerosis following intrahippocampal kainate injection in C57BL/6J mice. Epilepsy Behav. 37, 175-183. doi: 10.1016/j.yebeh.2014. 06.033

Paredes, M. F., Greenwood, J., and Baraban, S. C. (2003). Neuropeptide $Y$ modulates a $G$ protein-coupled inwardly rectifying potassium current in the mouse hippocampus. Neurosci. Lett. 340, 9-12. doi: 10.1016/S0304-3940(03)00036-3

Parker, S. L., Kane, J. K., Parker, M. S., Berglund, M. M., Lundell, I. A., and Li, M. D. (2001). Cloned neuropeptide Y (NPY) Y1 and pancreatic polypeptide Y4 receptors expressed in Chinese hamster ovary cells show considerable agonistdriven internalization, in contrast to the NPY Y2 receptor. Eur. J. Biochem. 268, 877-886. doi: 10.1046/j.1432-1327.2001.01966.x

Patrylo, P. R., Van Den Pol, A. N., Spencer, D. D., and Williamson, A. (1999). NPY inhibits glutamatergic excitation in the epileptic human dentate gyrus. J. Neurophysiol. 82, 478-83. doi: 10.1152/jn.1999.82.1.478

Pedragosa-Badia, X., Stichel, J., and Beck-Sickinger, A. G. (2013). Neuropeptide y receptors: How to get subtype selectivity. Front. Endocrinol. 4:5. doi: $10.3389 /$ fendo.2013.00005

Pedrazzini, T., Pralong, F., and Grouzmann, E. (2003). Neuropeptide Y: the universal soldier. Cell. Mol. Life Sci. 60, 350-377. doi: 10.1007/s000180300029

Pernow, J., Lundberg, J. M., Kaijser, L., Hjemdahl, P., Theodorsson-Norheim, E., Martinsson, A., et al. (1986). Plasma neuropeptide Y-like immunoreactivity and catecholamines during various degrees of sympathetic activation in man. Clin. Physiol. 6, 561-578. doi: 10.1111/j.1475-097X.1986.tb00789.x

Pickel, V. M., Beck-Sickinger, A. G., Chan, J., and Wieland, H. A. (1998). Y1 receptors in the nucleus accumbens: ultrastructural localization and association with neuropeptide Y. J. Neurosci. Res. 52, 54-68. doi: 10.1002/(SICI)1097-4547(19980401)52:1<54::AID-JNR6>3.0.CO;2-J

Potter, E. K. (1987). Cardiac vagal action and plasma levels of neuropeptide $\mathrm{Y}$ following intravenous injection in the dog. Neurosci. Lett. 77, 243-247. doi: 10.1016/0304-3940(87)90594-5

Powell, K. L., Fitzgerald, X., Shallue, C., Jovanovska, V., Klugmann, M., Von Jonquieres, G., et al. (2018). Gene therapy mediated seizure suppression in genetic generalised epilepsy: neuropeptide $\mathrm{Y}$ overexpression in a rat model. Neurobiol. Dis. 113, 23-32. doi: 10.1016/j.nbd.2018.01.016

Rettenbacher, M., and Reubi, J. C. (2001). Localization and characterization of neuropeptide receptors in human colon. Naunyn. Schmiedebergs Arch. Pharmacol. 364, 291-304. doi: 10.1007/s002100 100454

Richichi, C., Lin, E. J. D., Stefanin, D., Colella, D., Ravizza, T., Grignaschi, G., et al. (2004). Anticonvulsant and antiepileptogenic effects mediated by adenoassociated virus vector neuropeptide $\mathrm{Y}$ expression in the rat hippocampus. J. Neurosci. 24, 3051-3059. doi: 10.1523/JNEUROSCI.4056-03.2004

Sajdyk, T. J., Schober, D. A., and Gehlert, D. R. (2002). Neuropeptide Y receptor subtypes in the basolateral nucleus of the amygdala modulate anxiogenic responses in rats. Neuropharmacology 43, 1165-1172. doi: 10.1016/S0028-3908(02)00234-4

Sajdyk, T. J., Shekhar, A., and Gehlert, D. R. (2004). Interactions between NPY and CRF in the amygdala to regulate emotionality. Neuropeptides 38, 225-234. doi: 10.1016/j.npep.2004.05.006

Satoh, C., Satoh, F., Takahashi, K., Murakami, O., Sone, M., Totsune, K., et al. (1999). Elevated plasma immunoreactive neuropeptide Y concentrations and its increased urinary excretion in patients with advanced diabetic nephropathy. Endocr. J. 46, 139-146. doi: 10.1507/endocrj.46.139

Shimada, K., Ohno, Y., Okamatsu-Ogura, Y., Suzuki, M., Kamikawa, A., Terao, A., et al. (2012). Neuropeptide y activates phosphorylation of ERK and STAT3 in stromal vascular cells from brown adipose tissue, but fails to affect thermogenic function of brown adipocytes. Peptides 34, 336-342. doi: 10.1016/j.peptides.2012.02.012

Silva, A. P., Xapelli, S., Grouzmann, E., and Cavadas, C. (2005a). The putative neuroprotective role of neuropeptide $\mathrm{Y}$ in the central nervous system. Curr. Drug Targets CNS Neurol. Disord. 4, 331-347. doi: 10.2174/1568007054546153

Silva, A. P., Xapelli, S., Pinheiro, P. S., Ferreira, R., Lourenço, J., Cristóvão, A., et al. (2005b). Up-regulation of neuropeptide $Y$ levels and modulation of glutamate release through neuropeptide $\mathrm{Y}$ receptors in the hippocampus of kainate-induced epileptic rats. J. Neurochem. 93, 163-170. doi: 10.1111/j.1471-4159.2004.03005.x

Sørensen, A. T., Kanter-Schlifke, I., Carli, M., Balducci, C., Noe, F., During, M. J., et al. (2008). NPY gene transfer in the hippocampus attenuates synaptic plasticity and learning. Hippocampus 18, 564-574. doi: 10.1002/hipo.20415

Sørensen, A. T., Nikitidou, L., Ledri, M., Lin, E. J. D., During, M. J., Kanter-Schlifke, I., et al. (2009). Hippocampal NPY gene transfer attenuates seizures without affecting epilepsy-induced impairment of LTP. Exp. Neurol. 215, 328-333. doi: 10.1016/j.expneurol.2008.10.015

Soud, K., Jørgensen, S. H., Woldbye, D. P. D., and Sørensen, A. T. (2019). The Cterminal flanking peptide of neuropeptide Y (NPY) is not essential for seizuresuppressant actions of prepro-NPY overexpression in male rats. J. Neurosci. Res. 97, 362-372. doi: 10.1002/jnr.24350

Sperk, G., Marksteiner, J., Gruber, B., Bellmann, R., Mahata, M., and Ortler, M. (1992). Functional changes in neuropeptide Y- and somatostatin-containing neurons induced by limbic seizures in the rat. Neuroscience 50, 831-846. doi: 10.1016/0306-4522(92)90207-I

Stanić, D., Brumovsky, P., Fetissov, S., Shuster, S., Herzog, H., and Hökfelt, T. (2006). Characterization of neuropeptide Y2 receptor protein expression in the mouse brain. I. Distribution in cell bodies and nerve terminals. J. Comp. Neurol. 499, 357-390. doi: 10.1002/cne.21046

Stanić, D., Mulder, J., Watanabe, M., and Hökfelt, T. (2011). Characterization of NPY Y2 receptor protein expression in the mouse brain. II. Coexistence with NPY, the Y1 receptor, and other neurotransmitter-related molecules. J. Comp. Neurol. 519, 1219-1257. doi: 10.1002/cne.22608

Stjernquist, M., and Owman, C. (1990). Further evidence for a prejunctional action of neuropeptide $\mathrm{Y}$ on cholinergic motor neurons in the rat uterine cervix. Acta Physiol. Scand. 138, 95-96. doi: 10.1111/j.1748-1716.1990.tb08817.x

St-Pierre, J. A., Nouel, D., Dumont, Y., Beaudet, A., and Quirion, R. (2000). Association of neuropeptide Y Y1 receptors with glutamate-positive and NPYpositive neurons in rat hippocampal cultures. Eur. J. Neurosci. 12, 1319-1330. doi: 10.1046/j.1460-9568.2000.00024.x

Tasan, R. O., Nguyen, N. K., Weger, S., Sartori, S. B., Singewald, N., Heilbronn, R., et al. (2010). The central and basolateral amygdala are critical sites of neuropeptide $\mathrm{Y} / \mathrm{Y} 2$ receptor-mediated regulation of anxiety and depression. J. Neurosci. 30, 6282-6290. doi: 10.1523/JNEUROSCI.0430-10.2010

Thiriet, N., Agasse, F., Nicoleau, C., Guégan, C., Vallette, F., Cadet, J. L., et al. (2011). NPY promotes chemokinesis and neurogenesis in the rat subventricular zone. J. Neurochem. 116, 1018-1027. doi: 10.1111/j.1471-4159.2010.07154.x

Thomas, L., Scheidt, H. A., Bettio, A., Huster, D., Beck-Sickinger, A. G., Arnold, K., et al. (2005). Membrane interaction of neuropeptide Y detected by EPR and NMR spectroscopy. Biochim. Biophys. Acta Biomembr. 1714, 103-113. doi: 10.1016/j.bbamem.2005.06.012

Tilan, J., and Kitlinska, J. (2016). Neuropeptide Y (NPY) in tumor growth and progression: Lessons learned from pediatric oncology. Neuropeptides 55, 55-66. doi: 10.1016/j.npep.2015.10.005

Tu, B., Timofeeva, O., Jiao, Y., and Nadler, J. V. (2005). Spontaneous release of neuropeptide $\mathrm{Y}$ tonically inhibits recurrent mossy fiber synaptic transmission in epileptic brain. J. Neurosci. 25, 1718-1729. doi: 10.1523/JNEUROSCI.4835-04.2005

van den Pol, A. N. (2012). Neuropeptide transmission in brain circuits. Neuron 76, 98-115. doi: 10.1016/j.neuron.2012.09.014

Verma, D., Tasan, R. O., Herzog, H., and Sperk, G. (2012). NPY controls fear conditioning and fear extinction by combined action on Y 1 and Y 2 receptors. Br. J. Pharmacol. 166, 1461-1473. doi: 10.1111/j.1476-5381.2012.01872.x 
Vezzani, A., Moneta, D., Mulé, F., Ravizza, T., Gobbi, M., and FrenchMullen, J. (2000). Plastic changes in neuropeptide Y receptor subtypes in experimental models of limbic seizures. Epilepsia 41, S115-S121. doi: 10.1111/j.1528-1157.2000.tb01569.x

Vezzani, A., and Sperk, G. (2004). Overexpression of NPY and Y2 receptors in epileptic brain tissue: an endogenous neuroprotective mechanism in temporal lobe epilepsy? Neuropeptides 38, 245-52. doi: 10.1016/j.npep.2004.05.004

Vrinda, M., Sasidharan, A., Aparna, S., Srikumar, B. N., Kutty, B. M., and Shankaranarayana Rao, B. S. (2017). Enriched environment attenuates behavioral seizures and depression in chronic temporal lobe epilepsy. Epilepsia 58, 1148-1158. doi: 10.1111/epi.13767

Wagner, L., Wolf, R., Zeitschel, U., Rossner, S., Petersén, Å., Leavitt, B. R., et al. (2015). Proteolytic degradation of neuropeptide y (NPY) from head to toe: identification of novel NPY-cleaving peptidases and potential drug interactions in CNS and Periphery. J. Neurochem. 135, 1019-1037. doi: 10.1111/jnc.13378

Wahlestedt, C., Pich, E. M., Koob, G. F., Yee, F., and Heilig, M. (1993). Modulation of anxiety and neuropeptide Y-Y1 receptors by antisense oligodeoxynucleotides. Science 259, 528-531. doi: 10.1126/science. 8380941

Wahlestedt, C., Yanaihara, N., and Håkanson, R. (1986). Evidence for different preand post-junctional receptors for neuropeptide $\mathrm{Y}$ and related peptides. Regul. Pept. 13, 307-318. doi: 10.1016/0167-0115(86)90048-0

Wai, S. M., Kindler, P. M., Lam, E. T. K., Zhang, A., and Yew, D. T. (2004). Distribution of neuropeptide Y-immunoreactive neurons in the human brainstem, cerebellum, and cortex during development. Cell. Mol. Neurobiol. 24, 667-684. doi: 10.1023/B:CEMN.0000036404.39432.0c

Waldbieser, G. C., Minth, C. D., Chrisman, C. L., and Dixon, J. E. (1992). Tissuespecific expression of the human neuropeptide $\mathrm{Y}$ gene in transgenic mice. Mol. Brain Res. 14, 87-93. doi: 10.1016/0169-328X(92)90014-3

Walther, C., Lotze, J., Beck-Sickinger, A. G., and Mörl, K. (2012). The anterograde transport of the human neuropeptide $\mathrm{Y} 2$ receptor is regulated by a subtype specific mechanism mediated by the C-terminus. Neuropeptides 46, 335-343. doi: 10.1016/j.npep.2012.08.011

Walther, C., Mörl, K., and Beck-Sickinger, A. G. (2011). Neuropeptide Y receptors: Ligand binding and trafficking suggest novel approaches in drug development. J. Pept. Sci. 17, 233-46. doi: 10.1002/psc.1357

Waschek, J. A. (1995). Transgenic targeting of neuroendocrine peptide genes in the hypothalamic-pituitary axis. Mol. Neurobiol. 10, 205-217. doi: 10.1007/BF02740676

Wickham, J., Ledri, M., Bengzon, J., Jespersen, B., Pinborg, L. H., Woldbye, D. P. D., et al. (2019). Inhibition of epileptiform activity by neuropeptide Y in brain tissue from drug-resistant temporal lobe epilepsy patients. Sci. Rep. 9, 19393-19393. doi: 10.1038/s41598-019-56062-1

Woldbye, D. P. D., Ängehagen, M., Gøtzsche, C. R., Elbrønd-Bek, H., Sørensen, A. T., Christiansen, S. H., et al. (2010). Adeno-associated viral vector-induced overexpression of neuropeptide y Y2 receptors in the hippocampus suppresses seizures. Brain 133, 2778-2788. doi: 10.1093/brain/awq219

Woldbye, D. P. D., Larsen, P. J., Mikkelsen, J. D., Klemp, K., Madsen, T. M., and Bolwig, T. G. (1997). Powerful inhibition of kainic acid seizures by neuropeptide Y via Y5- like receptors. Nat. Med. 3, 761-764. doi: 10.1038/nm0797-761

Woldbye, D. P. D., Nanobashvili, A., Sørensen, A. T., Husum, H., Bolwig, T. G., Sørensen, G., et al. (2005). Differential suppression of seizures via Y2 and Y5 neuropeptide Y receptors. Neurobiol. Dis. 20, 760-772. doi: 10.1016/j.nbd.2005.05.010

Wood, J., Verma, D., Lach, G., Bonaventure, P., Herzog, H., Sperk, G. et al. (2016). Structure and function of the amygdaloid NPY system: NPY Y2 receptors regulate excitatory and inhibitory synaptic transmission in the centromedial amygdala. Brain Struct. Funct. 221, 3373-3391. doi: 10.1007/s00429-015-1107-7

Yang, Z., Han, S., Keller, M., Kaiser, A., Bender, B. J., Bosse, M., et al. (2018). Structural basis of ligand binding modes at the neuropeptide y Y1 receptor. Nature 556, 520-524. doi: 10.1038/s41586-0180046-X

Yilmazer-Hanke, D., O’Loughlin, E., and Mcdermott, K. (2016). Contribution of amygdala pathology to comorbid emotional disturbances in temporal lobe epilepsy. J. Neurosci. Res. 94, 486-503. doi: 10.1002/jnr. 23689

Zanirati, G., Azevedo, P. N., Venturin, G. T., Greggio, S., Alcará, A. M., Zimmer, E. R., et al. (2018). Depression comorbidity in epileptic rats is related to brain glucose hypometabolism and hypersynchronicity in the metabolic network architecture. Epilepsia 59, 923-934. doi: 10.1111/epi.14057

Zhang, F., Zhao, W. Q., Li, W. L., Dong, C. Z., Zhang, X. Y., Wu, J., et al. (2013). Neuropeptide $Y$ gene transfection inhibits post-epileptic hippocampal synaptic reconstruction. Neural Regen. Res. 8, 1597-1605.

Zhou, Z., Zhu, G., Hariri, A. R., Enoch, M. A., Scott, D., Sinha, R., et al. (2008). Genetic variation in human NPY expression affects stress response and emotion. Nature 452, 997-1001. doi: 10.1038/nature06858

Ziffert, I., Kaiser, A., Babilon, S., Mörl, K., and Beck-Sickinger, A. G. (2020a). Unusually persistent Gai-signaling of the neuropeptide Y2 receptor depletes cellular Gi/o pools and leads to a Gi-refractory state. Cell Commun. Signal. 18:49. doi: 10.1186/s12964-020-00537-6

Ziffert, I., Kaiser, A., Hoppenz, P., Mörl, K., and Beck-Sickinger, A. G. (2020b). Shuttling of peptide-drug conjugates by $\mathrm{g}$ protein-coupled receptors is significantly improved by pulsed application. ChemMedChem. 16, 164-178. doi: $10.1002 / \mathrm{cmdc} .202000490$

Conflict of Interest: The authors declare that the research was conducted in the absence of any commercial or financial relationships that could be construed as a potential conflict of interest.

Copyright ( $\odot 2021$ Cattaneo, Verlengia, Marino, Simonato and Bettegazzi. This is an open-access article distributed under the terms of the Creative Commons Attribution License (CC BY). The use, distribution or reproduction in other forums is permitted, provided the original author(s) and the copyright owner(s) are credited and that the original publication in this journal is cited, in accordance with accepted academic practice. No use, distribution or reproduction is permitted which does not comply with these terms. 